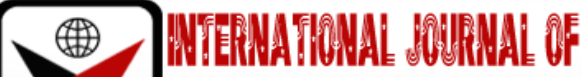

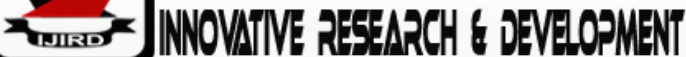

ISSN 2278-0211 (Online)

\section{Cognitive Challenges to Effective Teaching and Learning: Perspectives of Senior High School Teachers}

\author{
Francis Arthur \\ M.Phil. Candidate, Department of Business and Social Sciences Education, \\ University of Cape Coast, Ghana \\ Freda Awonakie Akwetey \\ M. Phil. Candidate, Department of Business and Social Sciences Education, \\ University of Cape Coast, Ghana
}

\begin{abstract}
This study investigated cognitive challenges to effective teaching in Senior High Schools in Gomoa East District. The study was quantitative research that adopted the descriptive cross-sectional survey design. In total, 110 SHS teachers were selected for the study. Data were collected through a 5-point Likert scale questionnaire ranging from strongly agree to strongly disagree. Descriptive (Mean and Standard Deviation) and inferential statistics (MANOVA) was used to analyse the data that were obtained. The study's result showed that the cognitive challenges to effective teaching are student mental mindset, metacognition, and self-regulation, student fear and mistrust, insufficient prior knowledge, misconceptions, ineffective learning strategies, transfer of learning, constraints of selective attention and constraints of mental effort and working memory. Also, it was found that there was no statistically significant difference in the perceptions of teachers about the cognitive challenges to effective teaching based on their sex, teaching experience and school proprietorship.It was recommended that irrespective of the teaching methods SHS teachers might choose to use, they should consider each of the challenges because each one can affect learning.
\end{abstract}

Keywords:Cognitive challenges, effective teaching, mental effort, mental mindset, metacognition, self-regulation, working memory

\section{Introduction}

Education forms the basis upon which the economic, social and political development of any nation is founded. Effective teaching plays a vital role in attaining all short-term and long-term goals of education. Teachers are one of the key elements in any school and effective teaching is one of the key propellers for school improvement. Many researchers and educationalists assert that education should be geared towards the holistic development (cognitive, affective and psychomotor domains) of the child.

Effective teaching involves a precise comprehension of the cognitive principles of learning. Even though that sounds clear, many teachers underrate the intricacy of effective teaching (Chew et al., 2018) or base their teaching method on misguided judgments, untested instincts, and false assumptions (Howard-Jones, 2014). According to Killen (2006), the effective teacher is the one who has clear objectives and own goals of teaching.

To enhance effective teaching and learning, teachers have to adapt effective strategies and pedagogies.Teachers must take into account the cognitive abilities of their learners when teaching. Cognitivists make the mental process the primary object of study and tries to discover and model the mental processes on the part of the learner during the learning process (Paper, Goyal, Choubey\& Yadav, 2011). Cognitive strategies have played a major role to design the learning system. The cognitive domain contains learning skills predominantly related to mental thinking processes. According to the newer version of Bloom's Taxonomy of Learning, learning processes in the cognitive domain include a hierarchy of skills involving processing information, constructing understanding, applying knowledge, solving problems, and conducting research. There are six levels of cognitive complexity: knowledge, comprehension, application, analysis, synthesis, evaluation.

Effective teaching and learning in senior high schools have been faced with several challenges such as teaching pedagogies adopted by teachers, learning difficulties, individual learning abilities, content appropriate, student truancy, unavailability and inadequate teaching and learning resources, poor supervision, among others. In the USA, Chew and Cerbin (2021) outline nine cognitive challenges to student learning. These challenges include student mental mindset, metacognition and self-regulation, student fear and mistrust, insufficient prior knowledge, misconceptions, ineffective learning strategies, transfer of learning, constraints of selective attention, and the constraints of mental effort and working 
memory. It has been observed by the researchers that several studies have been conducted on effective teaching and learning with little or no research on the cognitive challenges to effective teaching and learning.

Mental mindset refers to the students' attitudes, convictions and expectations about a subject (Chew, 2014; Farrington, 2013). This definition suggests that a mental mindset comprises the student's beliefs about their possibility of success in the subject, topics, teaching methods and the assessment techniques used by the teacher. The attitude of students towards a particular subject can predict student learning across different topics, subjects, teaching methods and assessments (Cahill et al., 2018). Also, some studies (Farrington, 2013; Farrington et al., 2012) found that students' mindset was an important element in enhancing student engagement.

Concerning metacognition and self-regulation, Flavell (1979) asserts that metacognition refers to one's awareness of and ability to regulate one's thinking. Similar to internal monitor, an active metacognitive awareness notices when a student's thoughtfulness diminishes when they have or have not grasped a concept sufficiently, when their thinking is defective, or when there are gaps in understanding. According to Ambrose et al. (2010), metacognition forms the basis for self-regulated learning which empowers students to plan, apply strategies, observe, appraise, and fine-tune their learning. Also, students may have false convictions that hinder their learning and they may not be able to evaluate their learning precisely (Bjork, Dunlosky\&Kornell, 2013; Kornell\& Finn, 2016; Morehead, Rhodes \&DeLozier, 2016).

On student fear and mistrust, in his book titled 'The College Fear Factor', Cox (2011) posited that fear can cause students and teachers to misinterpret each other's actions and intentions to the detriment of student success. Again, Yeager et al. (2014) investigated breaking the cycle of mistrust. In their study, they found that student mistrust can cause them to see constructive criticism from teachers as their bias towards them. Therefore, that students could ignore the feedback or constructive criticism from teachers (Yeager et al., 2014).Student trust predicts students' readiness to involve in more complex dynamic learning activities (Cavanagh et al., 2018). Likewise, Chew et al. (2018) opine that students' trust in the tutor improves their willingness to give their best effort and take on extra challenging tasks.

Also, insufficient prior knowledge is a crucial cause of learning difficulties (Chew \&Cerbin, 2021) since previous knowledge is the foundation upon which current information is built.They further asserted that insufficient prior knowledge may occur when learners lack prerequisite subjects and it may also be a result of inadequate preparation by students. Branford, Brown and Cocking (1999) opines that gaps in relevant previous knowledge make it arduous to explain, arrange, and recall current information. This assertion implies that learning involves using previous knowledge to learn and make meaning of new information.

Additionally, when learners' previous knowledge is inaccurate, they are likely to misinterpret, misunderstand, and disregard new information hence,a misconception can impede new learning (Chi, 2013; Taylor \& Kowalski, 2014). For instance, Busom, Lopez-Mayan, and Panades (2017) studied a variety of student misconceptions in introductory economics classes and observed that students' exposure to an economic principles course and doing well in exams and coursework hardly seems to affect misconceptions. This suggests that standard teaching practices may not be sufficiently effective in having students incorporate the tools of economic analysis into their reasoning processes, and consequently on their judgments and decisions.With regards to ineffective learning strategies, Blasiman, Dunlosky and Rawson (2017) found that students use strategies such as re-reading, highlighting, underlining, cramming and rote memorization.

Moreover, transfer of learning is whereby students relate what they have learned properly in different contexts. Chew and Cerbin (2021) opine that all teachers want students to retain and use the knowledge gained in a class beyond the immediate classroom environment.Also, students are apt to miss information during changes when they involve or withdraw from a task (Gazzaley\& Rosen, 2016). Generally, learning stifles whenever students have divided attention between two or more pieces of information. Schwartz, Tsang and Blair (2016a) assert that the amount of new information presented to students during classroom instruction is a major source of cognitive load.

However, several studies reviewed focused onthe various aspect of the cognitive challenges separately. Also, Chew and Cerbin's (2021) study did not directly evaluate the cognitive challenges to effective teaching but rather formulated a framework for assessing cognitive challenges to effective teaching. It is against this backdrop that the researchers seek to investigate the cognitive challenges to effective teaching and learning in selected senior high schools in the Gomoa East District.

\subsection{Purpose of the Study}

The main drive of this study was to investigate the cognitive challenges to effective teaching and learning in Senior

High Schools (SHS) in the Gomoa East District. In specific terms, the study sought to:

- Ascertain cognitive challenges to effective teaching and learning in Senior High Schools.

- Find out whether there is any statistically significant difference in the cognitive challenges to effective teaching with regard to gender.

- Determine whether there is any statistically significant difference in the cognitive challenges to effective teaching based on their teaching experience.

- Ascertain whether there is any statistically significant difference in the cognitive challenges to effective teaching based on school proprietorship.

\subsection{Research Hypotheses}

The study tested the following research hypotheses:

- $\mathrm{H}_{0}$ : There is no statistically significant difference in the cognitive challenges to effective teaching between male and female teachers. 
- $\mathrm{H}_{0}$ : There is no statistically significant difference in the cognitive challenges to effective teaching based on teaching experience.

- $\mathrm{H}_{0}$ : There is no statistically significant difference in the cognitive challenges to effective teaching between private and public teachers.

\section{Research Methods}

\subsection{Research Design, Population and Sampling}

The descriptive cross-sectional survey design was used to investigate the cognitive challenges to effective teaching and learning. This makes the study essential for inferences and generalisations (Osuala, 2001). Also, the descriptive cross-sectional survey design was employed for the study because it explains the state of affairs of the study population without manipulating the variables (Osuala, 2001). The population for the study comprised all Senior High School (SHS) teachers at public and private Senior High Schools in the Gomoa East District. In total, there are 6 SHS's in the Gomoa East District of which 4 are public schools while the remaining 2 are private schools. The total number of teachers in these schools was 120. The census method was used to involve all the teachers in the Senior High Schools in the Gomoa East District. Since no element of the population was left, highest accuracy was presumed (Kothari, 2004).

\subsection{Data Collection Instrument}

The cognitive challenges to the effective teaching framework proposed by Chew and Cerbin (2021) were adapted to design the questionnaire for the study. The questionnaire comprised 26 items grouped under sections A and B. The first section collected demographic data such as the name of the school, school proprietorship, sex, age, educational qualification and teaching experience of respondents. Section B consisted of 20 items and collected data on the cognitive challenges to effective teaching. The items were measured using a scale of 1 to 5 where $1=$ Strongly Disagree, $2=$ Disagree, $3=$ Neutral, $4=$ Agree and $5=$ Strongly Agree. A Cronbach Alpha of .927 was obtained as the reliability coefficient for the instrument. According to Fink (2017) a reliability coefficient of .70 or higher is considered acceptable in many social science research. Hence, the questionnaire was deemed reliable for the data collection.

\subsection{Data Collection Procedure}

The researchers personally visited all the sampled schools and administered the questionnaire. The Senior High School teachers were given fifteen (15) to thirty (30) minutes to respond to the items in the questionnaire. In all, the researchers collected 110 completed questionnaires of the entire 120 questionnaires that were distributed from all the teachers within the six (6) selected Senior High Schools. Hence, the return rate for the questionnaire was 91.67\%.

\subsection{Techniques of Data Analysis}

Data collected were encoded and refined with the aid of Statistical Product and Service Solutions (SPSS version 22). Descriptive and inferential statistics were used to analyse the data to provide the needed results. Specifically, mean and standard deviation were used to analyse the research question. The scale mean score interpretation is given as follows: 1.00-1.49 (Strongly Disagree); 1.50-2.49 (Disagree); 2.50-3.49 (Neutral); 3.50-4.49 (Agree); 4.50-5.00 (Strongly Agree). Finally, the research hypotheses were analysed using Multivariate Analysis of Variance (MANOVA).

\section{Presentation of Results}

3.1. Research Question One: What Are the Cognitive Challenges to Effective Teaching in Senior High Schools? Table 1 presents the results of the cognitive challenges to effective teaching in Senior High Schools.

\begin{tabular}{|c|c|c|c|}
\hline S/N & Cognitive Challenges & M & SD \\
\hline 1 & Student mental mindset (SMM) & 4.32 & .78 \\
\hline 2 & Metacognition and self-regulation (MS) & 4.08 & .88 \\
\hline 3 & Student fear and mistrust (SFM) & 4.00 & .92 \\
\hline 4 & Insufficient prior knowledge (IPK) & 4.14 & .86 \\
\hline 5 & Misconceptions (M) & 3.95 & .93 \\
\hline 6 & Ineffective learning strategies (ILS) & 3.88 & 1.02 \\
\hline 7 & Transfer of learning (TL) & 3.87 & 1.02 \\
\hline 8 & Constraints of selective attention (CSA) & 3.81 & 1.04 \\
\hline 9 & Constraints of mental effort and working memory (CMW) & 3.88 & 1.02 \\
\hline & Average Mean/Average Standard Deviation & 3.99 & .94 \\
\hline
\end{tabular}

Table 1: Cognitive Challenges to Effective Teaching

Scale M: 1.00-1.49 (Strongly Disagree), 1.50-2.49 (Disagree), 2.50-3.49 (Neutral), 3.50-4.49 (Agree), 4.50-5.00 (Strongly Agree). Source: Fieldwork (2021)

From Table 1, the average mean of 3.99 compared to the cut-off point of 3.50-4.49 for agreement to most of the items, shows that the Senior High School teachers affirmed that the cognitive challenges to effective teaching are student 
mental mindset, metacognition and self-regulation, student fear and mistrust, insufficient prior knowledge, misconceptions, ineffective learning strategies, transfer of learning, constraints of selective attention and constraints of mental effort and working memory. They were of the view that students may believe a subject or topic is irrelevant to them $(\mathrm{M}=4.23, \mathrm{SD}=.75)$. Also, teachers affirmed that students may be overconfident in their level of understanding ( $\mathrm{M}=$ $3.97, \mathrm{SD}=.90)$. Additionally, teachers confirmed that students come to a subject or topic with a certain level of fear $(\mathrm{M}=$ $4.02, \mathrm{SD}=.84)$.

Concerning prior knowledge, the respondents agreed that some students may have little to no knowledge about the content of the subject $(M=4.15, S D=.87)$. In furtherance, teachers acknowledged that students may cling to misconceptions even when taught accurate information $(M=3.87, S D=.94)$. As a result, students often prefer the least effective learning strategies $(M=3.68, S D=1.11)$. Concerning the transfer of learning, teachers agreed that students often fail to apply knowledge beyond the end of a subject (course) or a lesson $(\mathrm{M}=3.88, \mathrm{SD}=.99)$. It was confirmed by teachers that students mistakenly believe they can multitask $(\mathrm{M}=3.80, \mathrm{SD}=1.03)$. Lastly, the respondents agreed that students have a limitation in cognitive processing such as the ability to hold information consciously $(\mathrm{M}=3.83, \mathrm{SD}=.99)$.

\subsection{Research Hypothesis One}

- $\mathrm{H}_{0}$ : There is no statistically significant difference in the cognitive challenges to effective teaching based on gender.

- $\mathrm{H}_{1}$ : There is a statistically significant difference in the cognitive challenges to effective teaching based on gender.

The test of difference through MANOVA was conducted after the establishment of the correlation among the elements of the cognitive challenge. The reason for establishing correlation was that MANOVA is wasteful when dependent variables are uncorrelated (Tabachnick\&Fidell, 2007). Also, Maxwell (2001) opined that the dependent variables should correlate from .3 to .7. The correlation results among the dependent variables (student mental mindset, metacognition and self-regulation, student fear and mistrust, insufficient prior knowledge, misconceptions, ineffective learning strategies, transfer of learning, constraints of selective attention and constraints of mental effort and working memory) are indicated in Table 2 .

\begin{tabular}{|c|c|c|c|c|c|c|c|c|c|}
\hline $\begin{array}{c}\text { Dimensions } \\
\text { of Cognitive } \\
\text { Challenges }\end{array}$ & SMM & MS & SFM & IPK & M & ILS & TL & CSA & CMW \\
\hline SMM & 1 & $.556^{* *}$ & $.534^{* *}$ & $.313^{* *}$ & $.309^{* *}$ & $.383^{* *}$ & $.305^{* *}$ & $.223^{* *}$ & $.208^{* *}$ \\
\hline MS & $.556^{* *}$ & 1 & $.558^{* *}$ & $.553^{* *}$ & $.538^{* *}$ & $.408^{* *}$ & $.282^{* *}$ & $.235^{* *}$ & $.230^{* *}$ \\
\hline SFM & $.534^{* *}$ & $.558^{* *}$ & 1 & $.599^{* *}$ & $.417^{* *}$ & $.388^{* *}$ & $.390^{* *}$ & $.438^{* *}$ & $.498^{* *}$ \\
\hline IPK & $.313^{* *}$ & $.553^{* *}$ & $.599^{* *}$ & 1 & $.680^{* *}$ & $.601^{* *}$ & $.537^{* *}$ & $.408^{* *}$ & $.479^{* *}$ \\
\hline M & $.309^{* *}$ & $.538^{* *}$ & $.417^{* *}$ & $.680^{* *}$ & 1 & $.752^{* *}$ & $.610^{* *}$ & $.396^{* *}$ & $.470^{* *}$ \\
\hline ILS & $.383^{* *}$ & $.408^{* *}$ & $.388^{*}$ & $.601^{* *}$ & $.752^{* *}$ & 1 & $.663^{* *}$ & $.485^{* *}$ & $.521^{* *}$ \\
\hline TL & $.305^{* *}$ & $.282^{* *}$ & $.390^{* *}$ & $.537^{* *}$ & $.610^{* *}$ & $.663^{* *}$ & 1 & $.691^{* *}$ & $.717^{* *}$ \\
\hline CSA & $.223^{* *}$ & $.235^{* *}$ & $.438^{* *}$ & $.408^{* *}$ & $.396^{* *}$ & $.485^{* *}$ & $.691^{* *}$ & 1 & $.808^{* *}$ \\
\hline CMW & $.208^{* *}$ & $.230^{* *}$ & $.498^{* *}$ & $.479^{* *}$ & $.470^{* *}$ & $.521^{* *}$ & $.717^{* *}$ & $.808^{* *}$ & 1 \\
\hline
\end{tabular}

Table 2: Correlation Matrix for Cognitive Challenges Dimensions

** Correlation Is Significant at.01 Level (2-Tailed)

Source: Fieldwork (2021)

In Table 2, the correlation observed among the dependent variables is significant. Hence, MANOVA was used to determine the differences in SHS teachers' perception about the cognitive challenges to effective teaching based on sex, teaching experience and school proprietorship. The results from the MANOVA are shown in Tables 3, 4 and 5.

\begin{tabular}{|c|c|c|c|c|c|c|c|}
\hline Effect & & Value & $\mathbf{F}$ & $\begin{array}{c}\text { Hypothesis } \\
\mathbf{d f}\end{array}$ & Error df & Sig. & $\begin{array}{c}\text { Partial Eta } \\
\text { Squared }\left(\boldsymbol{\eta}_{\boldsymbol{p}}^{\mathbf{2}}\right)\end{array}$ \\
\hline Sex & Pillai's Trace & .104 & 1.283 & 9.000 & 100.000 & .256 & .104 \\
\hline & Wilks' Lambda & .896 & 1.283 & 9.000 & 100.000 & .256 & .104 \\
\hline & Hotelling's Trace & .115 & 1.283 & 9.000 & 100.000 & .256 & .104 \\
\hline & Roy's Largest Root & .115 & 1.283 & 9.000 & 100.000 & .256 & .104 \\
\hline
\end{tabular}

Table 3: MANOVA Results of Differences in Cognitive Challenges Based on Sex

Source: Fieldwork (2021)

Significant at .05 Level

The test of homogeneity of variance-covariance matrices based on Box's M test was conducted, $M=104.919, \mathrm{~F}(45$, $38211.71)=2.126, p=.000$. Hence, the assumption of the equality of homogeneity of variance-covariance matrices has been violated. Pillai's Trace was therefore reported in testing for statistical significance. From Table 3, it can be observed that there is no statistically significant difference in the perceptions of teachers about the cognitive challenges to effective teaching based on their sex, $\mathrm{F}(9,100)=1.283, p=.256$; Pillai's Trace $=.104, \eta_{p}^{2}=.104$. This result suggests that the perceptions of teachers about the cognitive challenges to effective teaching were not significantly dependent on their sex. 


\subsection{Research Hypothesis Two}

- $\mathrm{H}_{0}$ : There is no statistically significant difference in the cognitive challenges to effective teaching based on teaching experience.

- $\mathrm{H}_{1}$ : There is a statistically significant difference in the cognitive challenges to effective teaching based on teaching experience.

\begin{tabular}{|c|c|c|c|c|c|c|c|}
\hline Effect & Value & $\mathbf{F}$ & $\begin{array}{c}\text { Hypothesis } \\
\text { df }\end{array}$ & Error df & Sig. & $\begin{array}{c}\text { Partial Eta } \\
\text { Squared }\left(\boldsymbol{\eta}_{\boldsymbol{p}}^{\mathbf{2}}\right)\end{array}$ \\
\hline $\begin{array}{c}\text { Teaching } \\
\text { Experience }\end{array}$ & Pillai's Trace & .353 & .844 & 45.000 & 500.000 & .754 & .071 \\
\hline & Wilks' Lambda & .691 & .827 & 45.000 & 432.534 & .781 & .071 \\
\hline & Hotelling's Trace & .386 & .810 & 45.000 & 472.000 & .807 & .072 \\
\hline & Roy's Largest Root & .118 & 1.316 & 9.000 & 100.000 & .238 & .106 \\
\hline
\end{tabular}

Table 4: MANOVA Results of Differences in Cognitive Challenges Based on Teaching Experience

Source: Fieldwork (2021)

Significant At.05 Level

The test of homogeneity of variance-covariance matrices based on Box's M test was conducted, $\mathrm{M}=321.050, \mathrm{~F}$ $(135,10691.98)=1.903, p=.000$. Hence, the assumption of the equality of homogeneity of variance-covariance matrices has been violated. Pillai's Trace was therefore reported in testing for statistical significance. It can be observed from Table 4 that there is no statistically significant difference in the perceptions of teachers about the cognitive challenges to effective teaching based on their teaching experience, $\mathrm{F}(45,500)=.844, p=.754$; Pillai's Trace $=.353, \eta_{p}^{2}=.071$. This finding means that the perceptions of teachers about the cognitive challenges to effective teaching were not significantly dependent on their teaching experience.

\subsection{Research Hypothesis Three}

- $\mathrm{H}_{0}$ : There is no statistically significant difference in the cognitive challenges to effective teaching between private and public teachers.

- $\mathrm{H}_{1}$ : There is a statistically significant difference in the cognitive challenges to effective teaching between private and public teachers.

\begin{tabular}{|c|c|c|c|c|c|c|c|}
\hline Effect & Value & F & $\begin{array}{c}\text { Hypothesis } \\
\mathbf{d f}\end{array}$ & Error df & Sig. & $\begin{array}{c}\text { Partial Eta } \\
\text { Squared }\left(\boldsymbol{\eta}_{\boldsymbol{p}}^{\mathbf{2}}\right)\end{array}$ \\
\hline $\begin{array}{c}\text { School } \\
\text { Proprietorship }\end{array}$ & Pillai's Trace & .098 & 1.201 & 9.000 & 100.000 & .303 & .098 \\
\hline & Wilks' Lambda & .902 & 1.201 & 9.000 & 100.000 & .303 & .098 \\
\hline & Hotelling's Trace & .108 & 1.201 & 9.000 & 100.000 & .303 & .098 \\
\hline & $\begin{array}{c}\text { Roy's Largest } \\
\text { Root }\end{array}$ & .108 & 1.201 & 9.000 & 100.000 & .303 & .098 \\
\hline
\end{tabular}

Table 5: MANOVA Results of Differences in Cognitive Challenges Based on School Proprietorship

Source: Fieldwork (2021)

Significant at .05 Level

The test of homogeneity of variance-covariance matrices based on Box's M test was conducted, $\mathrm{M}=88.984, \mathrm{~F}$ (45, $806.75)=1.173, p=.206$. This reveals that the assumption of the equality of homogeneity of variance-covariance matrices has not been violated. Since there was no violation of homogeneity of variance-covariance matrices, Wilk's Lambda $\left(\Lambda_{\mathrm{W}}\right)$ test was reported in testing for statistical significance. From Table 5 , it can be observed that there is no statistically significant difference in the perceptions of teachers about the cognitive challenges to effective teaching based on their school proprietorship, $\mathrm{F}(9,100)=1.201, p=.303 ; \Lambda_{\mathrm{W}}=.902, \eta_{p}^{2}=.098$. This result implies that the perceptions of teachers about the cognitive challenges to effective teaching were not significantly dependent on their school proprietorship.

\section{Discussion of Results}

The study investigated the cognitive challenges to effective teaching and learning in Senior High Schools in the Gomoa East District. This is essential because Chew and Cerbin (2021) assert that the cognitive challenges to effective teaching are contextual. The study's result revealed that the cognitive challenges to effective teaching and learning are student mental mindset, metacognition and self-regulation, student fear and mistrust, insufficient prior knowledge, misconceptions, ineffective learning strategies, transfer of learning, constraints of selective attention and constraints of mental effort and working memory. This result suggests that these cognitive restrictions pose challenges to effective teaching and learning. The study's finding validates the nine cognitive challenges framework formulated by Chew and Cerbin (2021). Concerning student mental mindset, the finding of the study is in harmony with that of Farrington (2013) who asserted that students' mindsets affect their attitudes towards a subject. Also, Kornell and Finn (2016) posited students' false beliefs and misconceptions about a subject undermine their learning. With regards to student fear and mistrust, the study's result is in tandem with that of Cox (2011) found that student fear can cause misunderstanding 
between students and teachers. In furtherance to this, Cavanagh et al. (2018) opined that students' trust affects their willingness to engage in learning activities.

The study found out that there was no statistically significant difference in the cognitive challenges to effective teaching based on sex, teaching experience and school proprietorship.The study's result implies that the cognitive challenges are not sensitive to the background characteristics (sex, teaching experience and school proprietorship) of teachers. Therefore, in addressing the cognitive challenges, no distinct attention should be placed on these characteristics.

\section{Conclusion and Recommendations}

This current study vividly shows that certain cognitive challenges hinder effective teaching and learning. It was revealed from the study that sex, teaching experience and school proprietorship do not influence the cognitive challenges to effective teaching. Therefore, in addressing the cognitive challenges to effective teaching, every SHS teacher should be involved and employ different teaching methods or approaches that address these challenges. The study focused on cognitive challenges to effective and learning from teachers' perspectives, however, students' views could have been solicited to enrich the findings of the study. This study was restricted to Chew and Cerbin's (2021) cognitive challenges to an effective teaching framework. Although this study focused on cognitive challenges, this study did not look at social and emotional factors in learning hence, further studies should focus on other challenges to effective teaching and learning.

\section{References}

i. Ambrose, S. A., Bridges, M., DiPietro, M., Lovett, M. C., \& Norman, M. K. (2010). How learning works: Seven researchbased principles for smart teaching. San Francisco: Jossey-Bass.

ii. Bjork, R. A., Dunlosky, J., \&Kornell, N. (2013). Self-regulated learning: Beliefs, techniques, and illusions. Annual Review of Psychology, 64, 417-444.

iii. Blasiman, R. N., Dunlosky, J., \& Rawson, R. A. (2017). The what, how much, and when of study strategies: Comparing intended versus actual study behaviour. Memory, 25(6), 784-792.

iv. Bransford, J. D., Brown, A. L., \& Cocking, R. R. (1999). How people learn: Brain, mind, experience, and school. Washington, DC: National Academy Press.

v. Busom, I., Lopez-Mayan, C., \&Panades, J. (2017). Students' persistent preconceptions and learning economic principles. Journal of Economic Education, 48(2), 74-92.

vi. Cahill, M. J., McDaniel, M. A., Frey, R. F., Hynes, K. M., Repice, M., Zhao, J., \&Trousil, R. (2018). Understanding the relationship between student attitudes and student learning. Physical Review Physics Education Research, 14(1), 116.

vii. Cavanagh, A. J., Chen, X., Bathgate, M., Frederick, J., Hanauer, D. I., \& Graham, M. J. (2018). Trust, growth mindset, and student commitment to active learning in a college science course. CBE-Life Sciences Education, 17(1).

viii. Chew, S. L. (2014). Helping students to get the most out of studying. In Applying science of learning in education: Infusing psychological science into the curriculum, ed. V. A. Benassi, C. E. Overson, \&C. M. Hakala (pp. 215-224). Washington, DC: Society for the Teaching of Psychology

ix. Chew, S. L., \&Cerbin, W. J. (2021). The cognitive challenges of effective teaching. The Journal of Economic Education, 52(1), 17-40.

x. Chew, S. L., Halonen, H. S., McCarthy, M. A., Gurung, R. A. R., Beers, M. J., McEntarffer, R., \& Landrum, R. E. (2018). Practice what we teach: Improving teaching and learning in psychology. Teaching of Psychology, 45(3), $239-245$.

xi. Chi, M. T. H. (2013). Two kinds and four sub-types of misconceived knowledge, ways to change it and the learning outcomes. In International handbook of research on conceptual change, 2nd ed., ed. S. Vosniadou (pp. 49-70). New York: Routledge Press.

xii. Cox, R. D. (2011). The college fear factor: How students and professors misunderstand one another. Cambridge, MA: Harvard University Press.

xiii. Farrington, C. A. (2013). Academic mindsets as a critical component of deeper learning. Chicago, IL: University of Chicago, Consortium on Chicago School Research.

xiv. Farrington, C., Roderick, M., Allensworth, E., Nagaoka, J., Keyes, T., Johnson, D., \&Beechum, N. (2012). Teaching adolescents to become learners. The role of noncognitive factors in shaping school performance: A critical literature review. Chicago, IL: University of Chicago, Consortium on Chicago School Research.

xv. Fink, A. (2017). How to conduct surveys: A step by step guide (6th ed.). Thousand Oaks, CA: Sage Publications.

xvi. Flavell, J. H. (1979). Metacognition and cognitive monitoring: A new area of cognitive-developmental inquiry. American Psychologist, 34(10), 906-911.

xvii. Gazzaley, A., \& Rosen, L. D. (2016). The distracted mind: Ancient brains in a high-tech world. Cambridge, MA: MIT Press.

xviii. Goyal, M., Choubey, A., \& Yadav, D. (2011). Cognitive models and its current challenges. In International Conference on Information Intelligence, Systems, Technology and Management (pp. 355-358). Springer, Berlin, Heidelberg.

xix. Howard-Jones, P. A. (2014). Neuroscience and education: Myths and messages. Nature Reviews: Neuroscience, 15(12), 817-824.

xx. Killen, R. (2006). Effective teaching strategies: Lessons for research and practice (4thed.). Thomson, Social Science Press, UK.

xxi. Kornell, N., \& Finn, B. (2016). Self-regulated learning: An overview of theory and data. In J. Dunlosky, \& S. K. Tauber (Eds.), The Oxford handbook of metamemory(pp. 325-340). New York: Oxford University Press.

xxii. Kothari, C. R. (2004). Research methodology: Method and techniques. New Age International. 
xxiii. Maxwell, S. (2001). When to use MANOVA and significant MANOVAs and insignificant ANOVAs or vice versa. Journal of Consumer Psychology, 10(1/2), 29-30.

xxiv. Morehead, K., Rhodes, M. G., \&DeLozier, S. (2016). Instructor and student knowledge of study strategies. Memory, 24(2), 257-271.

xxv. Osuala, E. C. (2001). Introduction to research methodology (3rd ed.). Africana-Fep Publishers Ltd.

xxvi. Schwartz, D. L., Tsang, J. M., \& Blair, K. P. (2016a). The ABCs of how we learn: 26 scientifically proven approaches, how they work, and when to use them. New York: Norton.

xxvii. Tabachnick, B. G., \&Fidell, L. S. (2007). Using multivariate statistics (5th ed.). Pearson.

xxviii. Taylor, A., \&Kowalski, P. (2014). Student misconceptions: Where do they come from and what can we do? In V. A. Benassi, C. E. Overson, \& C. M. Hakala (Eds.), Applying science of learning in education: Infusing psychological science into the curriculum(pp. 259-273). Washington, DC: Society for the Teaching of Psychology.

xxix. Yeager, D. S., Purdie-Vaughns, V., Garcia, J., Apfel, N., Brzustoski, P., Master, A.,Hessert, W. T., Williams, M. E., \& Cohen, G. L.(2014). Breaking the cycle of mistrust: Wise interventions to provide critical feedback across the racial divide. Journal of Experimental Psychology: General 143(2), 804-824. 